\title{
Deletion of sorting nexin 27 suppresses proliferation in highly aggressive breast cancer MDA-MB-231 cells in vitro and in vivo
}

Jilei Zhang ${ }^{1+}$, Kendy $\mathrm{Li}^{2+}$, Yongguo Zhang ${ }^{1}$, Rong $\mathrm{Lu}^{1}$, Shaoping $\mathrm{Wu}^{3}$, Jingrong Tang ${ }^{4}$, Yinglin Xia ${ }^{1}$ and Jun Sun ${ }^{1 *}$ (D)

\begin{abstract}
Background: Sorting Nexin 27 (SNX27) belongs to a family of sortin nexins and possesses a unique binding domain at the C-terminus which mediates protein-protein interaction in intracellular trafficking, membrane remodeling, organelle motility, and tight junctions. However, its role in cancer development, especially in vivo, remains largely unknown.
\end{abstract}

Methods: We have generated a stable SNX27 knockdown clone in a highly aggressive breast cancer cell line MDAMB-231 using an inducible lentiviral shRNA system. Cell migration and proliferation of SNX27 knockdown (KD) cells were compared with wild-type (WT) cells by MTT and wound healing assay, respectively. The differences in colony formation between SNX27-KD and WT cells were detected by soft agar culture and matrigel 3D culture. Furthermore, tumor growth was examined in a xenograft nude mouse model using SNX27-KD and WT MDA-MB231 cells. The critical EMT (epithelial-mesenchymal transition) regulators were examined in vitro and in vivo.

Results: The wound healing assay showed that SNX27 knockdown significantly decreased cell motility and proliferation. Colony formation in soft agar showed that the SNX27 knockdown cells formed significantly fewer and smaller colonies than the parental MDA-MB-231 cells. Western blots and immunostaining showed that knockdown of SNX27 led to increased expression of E-cadherin and $\beta$-catenin proteins, which facilitate adhesion formation and reverse EMT. EMT is a cellular program that allows polarized, immotile epithelial cells to convert to motile mesenchymal cells, promoting carcinoma invasion. The expression levels of Vimentin, the transcription factor of EMT, and tight junction protein Claudin-5, were significantly diminished in the SNX27 knockdown cells. The expression of PCNA, the cell proliferation marker, was increased in SNX27-KD cells transfected with E-cadherin siRNA. In a xenograft nude mouse model, we found that knockdown of SNX27 significantly inhibited tumor growth. The tumors from mice with SNX27-KD cells showed less proliferation compared to tumors from mice injected with wildtype cells. The increase in E-cadherin and $\beta$-catenin and decrease in Vimentin and Claudin-5 were observed in tumors of mice injected with SNX27-KD cells.

Conclusions: Our data have demonstrated that SNX27 plays a crucial role in tumor growth in vitro and in vivo. Keywords: Epithelial-mesenchymal transition, Cell adhesion, Cell junctions, Breast cancer, Sorting nexin 27, Proliferation

\footnotetext{
* Correspondence: junsun7@uic.edu

${ }^{\dagger}$ Jilei Zhang and Kendy Li contributed equally to this work.

1 Division of Gastroenterology and Hepatology, Medicine, University of Illinois at

Chicago, 840 S Wood Street, Room 704 CSB, MC716, Chicago, IL 60612, USA

Full list of author information is available at the end of the article
}

(c) The Author(s). 2019 Open Access This article is distributed under the terms of the Creative Commons Attribution 4.0 International License (http://creativecommons.org/licenses/by/4.0/), which permits unrestricted use, distribution, and reproduction in any medium, provided you give appropriate credit to the original author(s) and the source, provide a link to the Creative Commons license, and indicate if changes were made. The Creative Commons Public Domain Dedication waiver (http://creativecommons.org/publicdomain/zero/1.0/) applies to the data made available in this article, unless otherwise stated. 


\section{Background}

Sorting Nexins (SNXs) are peripheral membrane proteins. They are grouped with the subfamily of the Phoxhomology (PX) domain family, based on the presence of SNX-PX domain [1, 2]. SNXs rescue transmembrane proteins from the lysosomal degradative pathway and facilitate their recycling to other cellular compartments as well as play roles in membrane trafficking, cell signaling, membrane remodeling, organelle motility, ion channel regulation and receptor recycling [1, 3]. The sorting nexin 27 (SNX27), which contains a PSD95, Dlg1, ZO-1 (PDZ)-binding motif, promotes recycling of internalized transmembrane proteins from endosomes to the plasma membrane by linking PDZ-dependent cargo recognition to retromer-mediated transport or regulate of endosome-to-plasma membrane recycling of transmembrane $[4,5]$. More than 100 cell surface proteins require SNX27-retromer, linking to prevent lysosomal degradation and maintain surface levels [5-8].

Breast cancer is the most common cancer in women. Approximately $90 \%$ of the deaths in breast cancer are caused by local invasion and distant metastasis [9-11]. Recent studies have revealed mechanisms through which multiple cancer cell and stromal cell subpopulations interact, including paracrine signaling, direct cell-cell adhesion, and remodeling of the extracellular matrix [10]. Three cell interaction mechanisms have emerged to explain how breast tumors become invasive: EMT, collective invasion, and the macrophage-tumor cell feedback loop $[10,11]$. EMT is a reversible and transient process which enables epithelial tumor cells to gain access to the vasculature and the formation of distant metastasis [12]. Multiple genes and proteins (e.g., Cadherins, $\beta$-catenin, and Vimentin) play crucial roles in EMT, thus serving as possible markers in the assessment of EMT. Cell-cell adhesion is mediated by a variety of membrane proteins, such as classical E or N-cadherins, claudins, and $\beta$ catenin [13-15]. Classical cadherins are essential in initiating cell-cell contacts. Moreover, E-cadherin is a tumor suppressor and used as a prognostic marker for breast cancer treatment $[15,16]$. Previous studies have reported that SNX27 regulates focal adhesions and cell motility [17] and polarizes to the apical membrane during NK cell migration [9]. SNX27 also interacts with Frizzled (Fzd) receptors to regulate the endocytosis and stability of Fzds and consequently mediates canonical Wnt/ $\beta$-catenin signalling [18]. However, whether SNX27 affects breast cancer has not been explored.

In the current study, we hypothesized that reduction of SNX27 in cancer cells suppresses proliferation. We compared the SNX27 levels in various breast cancer cell lines and selected a highly aggressive breast cancer cell line MDA-MB-231 with the highest level of SNX27 protein expression. We then generated a stable SNX27 knockdown clone in the MDA-MB-231 cells using an inducible lentiviral shRNA system. We showed that knockdown of SNX27 could reduce tumor cell migration, enhance the cell-cell contacts, and suppress cancer growth. Thus, our data suggest that SNX27 plays a critical role in cancer development.

\section{Methods \\ Materials}

The monoclonal antibody to human SNX27 (N-terminal amino acids 1-267) was purchased from Abcam (Cambridge, MA). Anti-GAPDH monoclonal antibody was purchased from Aldrich (St. Louis, MO). A whole set of the EMT Antibody Sampler Kit was purchased from Cell Signalling (Danvers, MA), including monoclonal antibodies to human $\beta$-catenin, E-cadherin, N-Cadherin, Vimentin and TCF- $\beta / Z E B 1$ raised in rabbit. Anti-human $\beta$-catenin, anti-human E-cadherin and anti-human Claudin-5 from BD Transduction (San Jose, CA), and anti-human $\beta$-actin from Sigma-Aldrich (St. Louis, MO) were used to western blot. Mouse monoclonal c-Myc antibody purchased from Santa Cruz Biotechnology (Dallas, TX) was used for the cMyc expression detection. The expression of PCNA was detected using mouse monoclonal PCNA antibody from Cell Signalling (Danvers, MA). All chemicals were purchased from Sigma-Aldrich unless otherwise stated. The highly aggressive breast cancer cell lines, including MDAMB-231, MDA-MB-435, MDA-MB-436, MCF-7A and MX1, were provided by Dr. Chu-Xia Deng's lab at National Institute of Diabetes and Digestive and Kidney Diseases (NIDDK), National Institutes of Health. (NIH). The SNX27 KD cell line was provided by Dr. Martin Playford at National Institutes of Health. MCF-10A (ATCC CRL10317) and MCF-10-2A (ATCC CRL-10781) were purchased from ATCC (Manassas, VA). All the cell lines were tested for mycoplasma contamination before being performed in this study using LookOut Mycoplasma PCR Detection Kit (Sigma-Aldrich, St. Louis, MO).

\section{Cell culture and Knock-down of SNX27 in MDA-MB-231 cells}

Cells were maintained in high glucose, Dulbecco's modified Eagle's medium (Invitrogen, Carlsbad, CA) supplemented with $10 \%$ fetal bovine serum (Invitrogen) in humidified chambers with $5 \% \mathrm{CO}_{2}$ at $37^{\circ} \mathrm{C}$. MCF-10AH1 cells were maintained in high glucose, Dulbecco's modified Eagle's medium (Invitrogen) supplemented with 10\% normal horse serum (Invitrogen, Carlsbad, CA). Stable shRNA expressing cells were generated using an inducible lentiviral shRNA system (pINDUCER10) and selected with Puromycin [15]. Clone 5 of shRNA of SNX27 has been used to target human SNX27 with the sequence TGGTCTGTAGTACTGTTCT. These sequences were subcloned from pGIPZ to pINDUCER10 with MluI and 
Xhol digests. An identical method was used to prepare control (firefly luciferase) lentivirus. Lentiviral supernatants were generated by transient transfection of MBAMD-231 cells using FuGENE HD [17]. Several clones were isolated and the expression of SNX27 was confirmed by western blot analysis with anti-SNX27 antibody. shRNA expression on puromycin-resistant clones were routinely induced with $1.5 \mu \mathrm{g} / \mathrm{ml}$ of doxycycline for $72-96 \mathrm{~h}$ prior to experimental analysis. The SNX27-KD clone could be maintained in selection medium with $2.5 \mu \mathrm{g} / \mathrm{ml}$ puromycin and $1.5 \mu \mathrm{g} / \mathrm{ml}$ doxycycline for several weeks.

\section{Western blot analysis}

Cells were rinsed twice with ice-cold HBSS, lysed in $250 \mu \mathrm{l}$ of ice-cold binding buffer 150 (BB150: $50 \mathrm{mM}$ Tris, pH 7.6, $150 \mathrm{mM} \mathrm{NaCl}, 0.2 \%$ CHAPS, $10 \mathrm{mM}$ EDTA) plus Complete TM protease inhibitor mixture (Roche Applied Science, Penzberg, Germany). The lysate was purified by centrifugation at $15,000 \mathrm{xg}$ for $10 \mathrm{~min}$ at $4{ }^{\circ} \mathrm{C}$ to clear the cellular debris. Total protein was quantified using the bicinchoninic acid assay (Pierce Biotechnology, Rockford, IL). Equal amount of protein was loaded on NuPAGE Novex $4-12 \%$ Bis-Tris in NuPAGE ${ }^{\bullet}$ MOPS SDS Running Buffer (Invitrogen, Carlsbad, CA), and transferred to nitrocellulose membrane by iBlot ${ }^{\circ}$ - Western Blotting System from Invitrogen. Immuno-detection was performed by blocking the membranes for $1 \mathrm{~h}$ in Blocking buffer (Licor, Lincoln NE). SNX27 was detected by primary antihuman SNX27 raised in rabbit (1:2000) followed by antirabbit secondary antibody conjugated to IRdye $780 \mathrm{~nm}$ (Licor, Lincoln, NE) at 1:10,000 dilution. The proteins associated with EMT including were with primary antibody raised in rabbit (1:1000) and followed by secondary antibodies conjugated to IRdye $780 \mathrm{~nm}$ at 1:10,000 dilution. The image was scanned and analyzed by Licor odyssey (Licor, Lincoln, NE). Detection of $\beta$-catenin, E-cadherin and Claudin-5 was performed using the primary antibody at 1:100 dilution followed by a secondary antibody conjugated to horseradish peroxidase and visualized by enhanced chemiluminescence (Thermo Scientific, Rockford, IL) [19]. All experiments were performed 3-5 times.

\section{Cell proliferation assay}

The SNX27-WT and SNX27-KD MDA-MB-231 cells were plated at a density of $1 \times 10^{4}$ cells per well in triplicate. After 24, 48 and $72 \mathrm{~h}$ of culture, the proliferation was evaluated by MTT Cell Proliferation Assay Kit (Thermo Fisher Scientific, Eugene, Oregon). Briefly, MDA-MB-231 cells were seeded in a 24-well plate at a density of $1 \times 10^{4}$ cells/well and allowed to adhere before processing. After removing the medium, $500 \mu \mathrm{l}$ per well of fresh culture medium without phenol red, and $50 \mu \mathrm{l}$ of $12 \mathrm{mM} 3-(4,5-$ dimethylthiazol-2-yl)-2, 5-diphenyltetrazolium bromide (MTT) stock solution were added to the wells and the
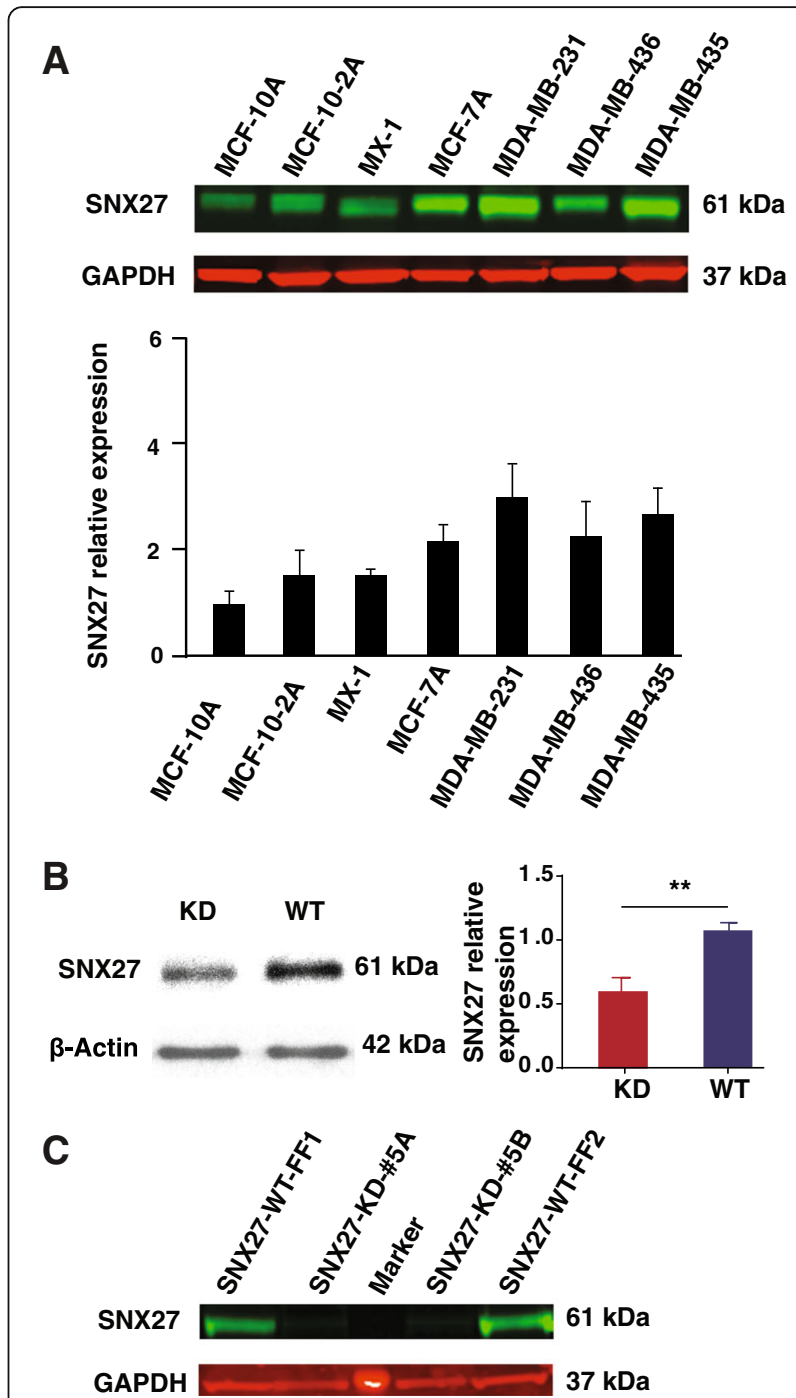

Fig. 1 The SNX27 expression in multi-cell lines and knockdown in MDAMB-231 cells. a Seven breast cancer cell lines were studied using western blot to detect the differences of SNX27 expression. The expression of SNX27 in MDA-MB-231 was the highest among the seven breast cancer cell lines, about three folds greater than MCF-10AH1's expression. The relative protein level of SNX27 was quantified with measurement of band intensity and normalized on the MCF-10AH1. Data are analyzed with Welch's t-test, and expressed as the mean \pm SD from three independent experiments $(n=3)$. $\mathbf{b}$ and $\mathbf{c}$ Western blot showed that stable SNX27-KD MDA-MB-231 cells were successfully generated using an inducible lentiviral shRNA system (pINDUCER10) after treating for 48-h (b) and 72-96 h (c). Data are analyzed with Welch's t-test, and expressed as the mean \pm SD from three independent experiments $(n=3)$. ${ }^{* *} p<$ 0.01 vs WT control. KD: knockdown of SNX27 in MDA-MB-231 cell; WT: wildtype of MDA-MB-231 cell

plate was incubated for $4 \mathrm{~h}$ at $37^{\circ} \mathrm{C}$ in dark conditions. After adding $500 \mu \mathrm{l}$ of the SDS- $\mathrm{HCl}$ solution prepared as the manufacture's instruction, each well was mixed thoroughly using the pipette. Absorbance was measured using an enzyme-linked immunosorbent assay (ELISA) reader at $570 \mathrm{~nm}$. Triplicate wells were counted for each time point 

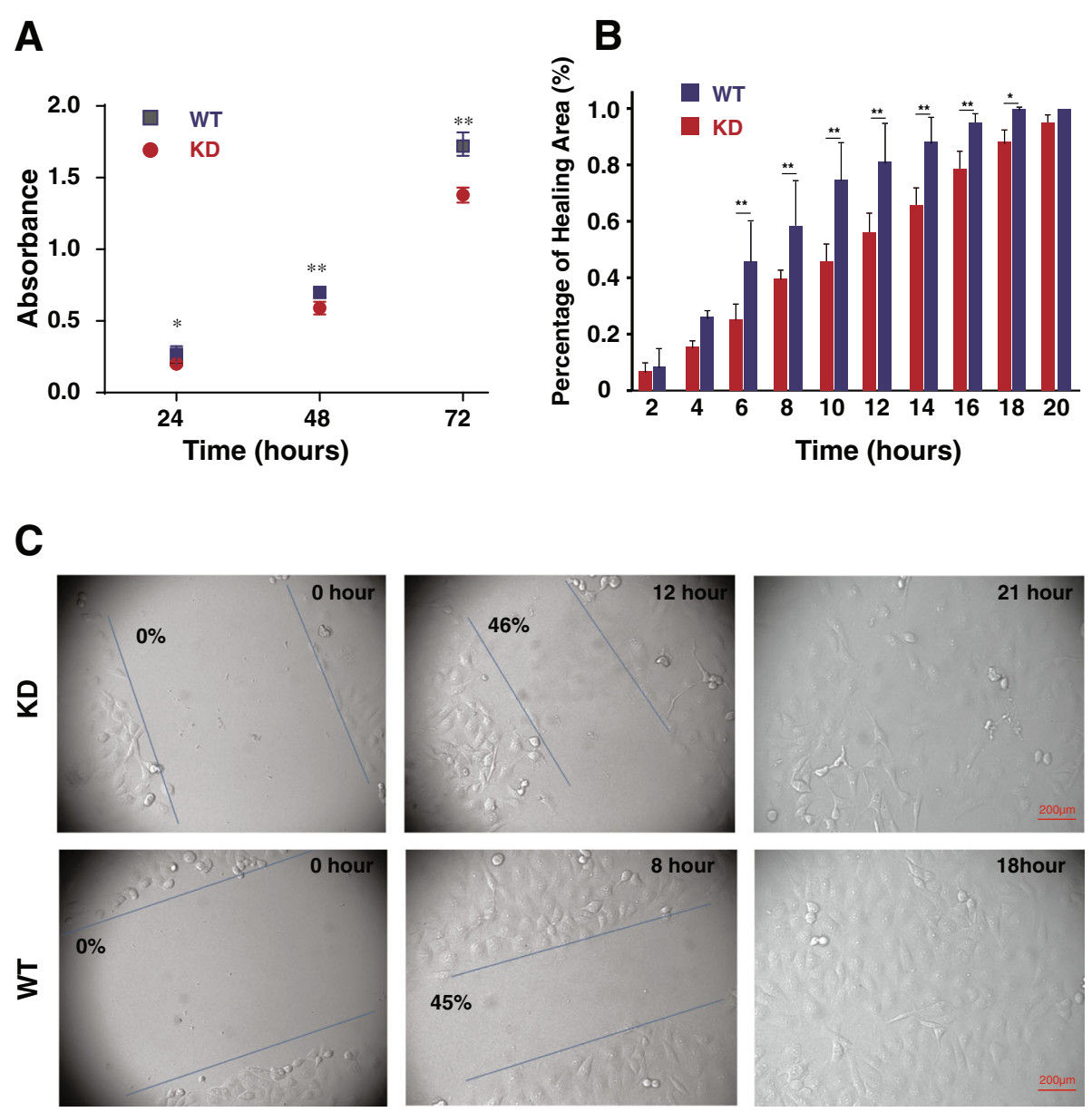

Fig. 2 Knockdown of SNX27 reduced the proliferation and migration of MDA-MB-231 breast cancer cells. a Proliferation of SNX27-KD MDA-MB231 cells was significantly decreased comparing with WT control MDA-MB-231 cells by MTT assay conducted at time points 24,48 , and $72 \mathrm{~h}$. Triplicate samples of each wafer from three independent experiments were included at each of the 3 time points $(n=3)$. Data are analyzed using generalized linear mixed models, and expressed as mean \pm SD. ${ }^{*} p<0.05$ vs. WT control; ${ }^{* *} p<0.01$ vs. WT control. b and $\mathbf{c}$ Wound healing analysis of SNX27-KD and WT MDA-MB-231 cells showed that the WT cancer cells can recover $\sim 50 \%$ of the wound area in $8 \mathrm{~h}$ and heal the whole area in $18 \mathrm{~h}$, but KD cells took $3 \mathrm{~h}$ longer than WT cancer cells to cover the whole wound area. Meanwhile, the percentages of healing area were showed with different time points. The migration rate was expressed as a percentage of scratch closure. The values are the means of three independent wound fields in three repeated time. Data are analyzed using generalized linear mixed models, and expressed as mean \pm SD from three independent experiments $(n=3) .{ }^{*} p<0.05$ vs. WT control; ** $p<0.01$ vs. WT control. Scale bar is $200 \mu \mathrm{m}$

and the whole experiment was repeated three times. The results were statistically analyzed using Welch's t-test.

\section{Wound healing assay}

Both WT and SNX27-KD clones of MBA-MD-231 cells were plated on fibronectin-coated $35 \mathrm{~mm}$ cover glassbottomed dishes (MatTek, Ashland, MA) and cultured in high glucose Dulbecco's modified Eagle's medium (Invitrogen) supplemented with $10 \%$ FBS, $2.5 \mu \mathrm{g} / \mathrm{ml}$ of Puromycin and $1.5 \mu \mathrm{g} / \mathrm{ml}$ of doxycycline in humidified chambers with $5 \% \mathrm{CO}_{2}$ at $37^{\circ} \mathrm{C}$. When cells were grown to confluency, the medium was aspirated, and the cell-coated surface was scraped with a $20-\mu \mathrm{l}$ pipette tip in a single stripe. The scrape-wounded surface was washed twice with $37^{\circ} \mathrm{C}$ warmed culture medium, and then the wounds in the cultures were allowed to heal for $24 \mathrm{~h}$ at $37^{\circ} \mathrm{C}$ in a Olympus Vivaview incubator microscope (Olympus Optical Co., Germany) with $5 \% \mathrm{CO}_{2}$. Migration of cells into wounded areas was captured at every $10 \mathrm{~min}$ for $24 \mathrm{~h}$ [20, 21]. The pictures were analyzed using a computer-assisted image analyzer (ImageJ, NIH, Bethesda, MD). The average extent of wound closure was evaluated by multiple measurements of area of the wound space in each of these cases. The migration rate was expressed as percentage of scratch closure and was calculated as follows: $\%$ of scratch closure $=a-b / a$, where (a) is an area between edges of the wound, and (b) is the area which remained cell-free during cell migration. The values are the means of three independent wound fields from three independent experiments. 

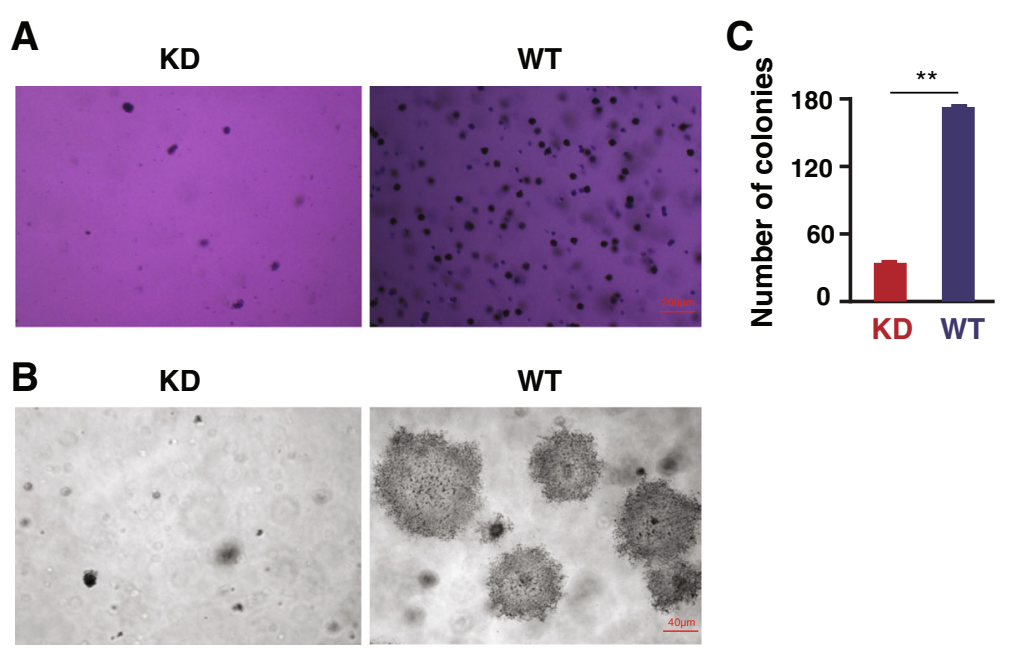

Fig. 3 The aggressiveness of SNX27-KD and WT MDA-MB-231 cells in soft agar. To investigate the influence of SNX27 on the aggressiveness of breast cancer MDA-MB-231 cells, the colony forming ability of SNX27-KD and WT MDA-MB-231 breast cancer cells, were observed by soft agar assays. The pictures taken under an inverted phase-contrast microscope with $4 \times(\mathbf{a}) 20 \times(\mathbf{b})$ magnifier object. c SNX27 knockdown cells formed significantly fewer colonies than the parental MDA-MB-231 cells. Data are analyzed with Welch's t-test, and expressed as mean \pm SD from three independent experiments $(n=3) .{ }^{* *} p<0.01$ vs. WT control

\section{Matrigel 3D culture}

WT or SNX27-KD clones of MBA-MD-231 cells were plated on Corning Costar Ultra-Low Attachment 96-well Plates and cultured in high glucose Dulbecco's modified Eagle's medium (Invitrogen, Carlsbad, CA) supplemented with $10 \% \mathrm{FBS}, 2.5 \mu \mathrm{g} / \mathrm{ml}$ of puromycin and $1.5 \mu \mathrm{g} / \mathrm{ml}$ of doxycycline in humidified chambers with $5 \% \mathrm{CO}_{2}$ at $37^{\circ} \mathrm{C}$ for $24 \mathrm{~h}$. Each cell cluster of SNX27-KD or WT was embedded in type I collagen gel solution (Cell-Matrix 3D cell culture kit, Nitta Gelatin Inc., Japan) at $5 \times 10^{4}$ cells $/ \mathrm{ml}$. The collagen gels were incubated at $37^{\circ} \mathrm{C}, 5 \% \mathrm{CO}_{2}$ for 30 min until the gel became solid.

Cells in the collagen gels were cultured in DMEM with $10 \%$ FBS and $2.5 \mu \mathrm{g} / \mathrm{ml}$ of Puromycin and $1.5 \mu \mathrm{g} / \mathrm{ml}$ of doxycycline in humidified chambers with $5 \% \mathrm{CO}_{2}$ at $37^{\circ} \mathrm{C}$ for $24 \mathrm{~h}$. To observe the $3 \mathrm{D}$ cell migration using nested collagen matrices, cultures were allowed to heal for $24 \mathrm{~h}$ at $37^{\circ} \mathrm{C}$ Olympus Vivaview incubator microscope (Olympus Optical Co., Germany) with $5 \% \mathrm{CO}_{2}$. Migration of cell clusters was captured at every $30 \mathrm{~min}$ for $48 \mathrm{~h}$ [20]. The pictures were analyzed using a computer-assisted image analyzer, ImageJ (Media Cybernetics, Bethesda, MD) [22]. The experiments were repeated at least three times.

\section{Assay for colony formation in soft agar}

Cell invasion ability was determined by the colony formation assay in soft agar [23]. Both WT and SNX27-KD MAD-MB-231 cells $\left(1 \times 10^{4}\right.$ cells/well $)$ were mixed with 2 $\mathrm{ml}$ of selection media containing $10 \% \mathrm{FBS}, 2.5 \mu \mathrm{g} / \mathrm{ml}$ of puromycin and $1.5 \mu \mathrm{g} / \mathrm{ml}$ of doxycycline and $0.5 \%$ agar (Sigma), and then overlaid on $2 \mathrm{ml}$ of $0.8 \%$ agar in 6-well culture dishes (Corning Inc. NY). The cells were kept in humidified chambers with $5 \% \mathrm{CO}_{2}$ at $37^{\circ} \mathrm{C}$ for $2-3$ weeks and the media were changed twice a week. After 2-3 weeks, colonies were visualized by staining with $0.05 \%$ crystal violet for $1 \mathrm{~h}$. The number of colonies was then counted at four equal, randomly selected points in each well under phase contrast time-lapse microscopy (Primo Vert, Carl Zeiss, Oberkochen, Germany) at a magnification of 4 or 10 folds. The images were captured and processed using ImageJ software (Media Cybernetics, Bethesda, MD). The number of invaded cells for each experimental sample represents the average of triplicate wells [24]. All experiments were performed at least three times.

\section{Immunofluorescence and confocal imaging}

WT and SNX27-KD MBA-MD-231 cells were plated on fibronectin-coated glass coverslips and cultured in high glucose Dulbecco's modified Eagle's medium (Invitrogen, Carlsbad, CA) supplemented with $10 \%$ fetal bovine serum, $2.5 \mu \mathrm{g} / \mathrm{ml}$ of puromycin and $1.5 \mu \mathrm{g} / \mathrm{ml}$ of doxycycline in humidified chambers with $5 \% \mathrm{CO}_{2}$ at $37^{\circ} \mathrm{C}$. Cells were fixed with $4 \%$ paraformaldehyde for $10 \mathrm{~min}$, permeabilized with $0.05 \%$ Triton X-100 for 5 min, washed with cold PBS twice, then incubated in blocking buffer (5\% goat serum in PBS) for $1 \mathrm{~h}$ at room temperature. The fixed coverslips were incubated with primary antibodies diluted 1:100 in blocking buffer overnight at $4{ }^{\circ} \mathrm{C}$. Coverslips were washed extensively with ice-cold PBS and incubated with the indicated secondary antibodies (Alexa Fluor 488, 568, 594, or $647 \mathrm{~nm}$, Invitrogen) used at 1:100 dilution in blocking buffer for $1 \mathrm{~h}$ at room temperature. Following further washing with PBS, coverslips were mounted using FluorSaveTM (Calbiochem). DAPI was added (Life 

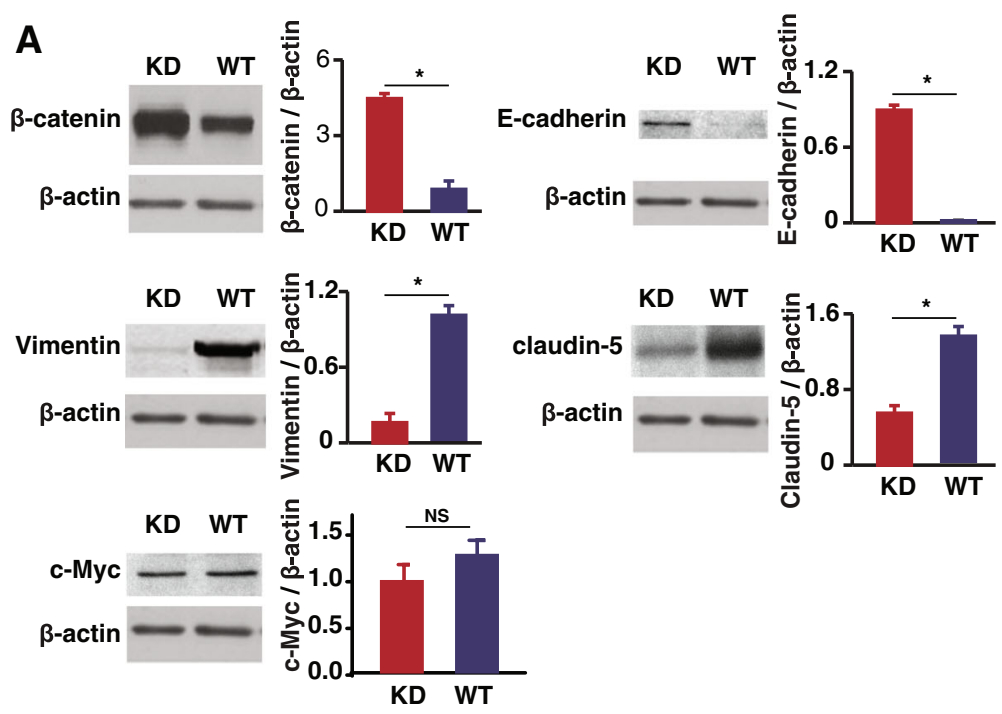

B
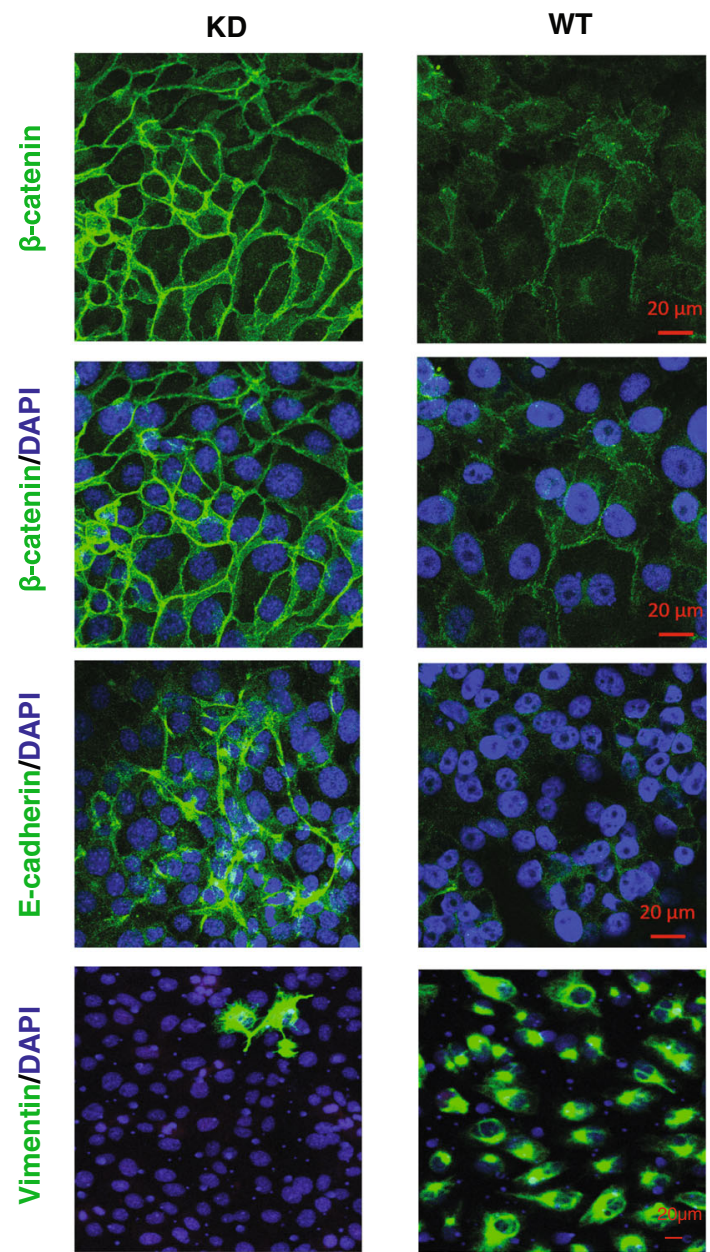

Fig. 4 (See legend on next page.) 
(See figure on previous page.)

Fig. 4 Expression of critical transcription factors of EMT in SNX27-KD and WT MDA-MB-231 breast cancer cells. a Western blots showed the protein expression of $\beta$-catenin and E-cadherin was significantly increased after SNX27 knockdown, whereas the expression of Vimentin and Claudin-5 were significantly reduced. However, there is no significantly difference of some other cell proliferation markers, like c-Myc, between KD and WT cells. Data are analyzed with Welch's t-test, and expressed with mean \pm SD from three independent experiments $(n=3) .{ }^{*} p<0.05$ vs. WT control; NS: no significantly difference vs. WT control. b SNX27-KD and WT MDA-MB-231 cells were immunostained with $\beta$-catenin, E-cadherin, and Vimentin, respectively. Knockdown of SNX27 led to enhanced $\beta$-catenin in cell membrane, which is involved in extracellular matrix formation with E-cadherin. The confocal imaging also confirmed that Vimentin is expressed at extremely low levels after SNX27 knockdown (Scale bar is $20 \mu \mathrm{m})$. Duplicate samples were included in three independent experiments $(n=3)$

technologies) for $1 \mathrm{~h}$ at room temperature. Slides were mounted with SlowFade (Life technologies), followed by a cover slip, and the edges were sealed to prevent drying. Specimens were imaged using a Zeiss ApoTome 2 microscopy, a Leica TGS SP5 confocal microscope or a Nikon Eclipse TE300 microscope (Leica, Germany). All experiments were performed multiple times using independent biological replicates.

\section{Small interfering RNA (siRNA) treatment}

SNX27-KD and WT MDA-MB-231 cells were plated in 12-well plates for $24 \mathrm{~h}$ before transfection. Cells were transfected with $25 \mathrm{nM}$ E-cadherin siRNA (Santa Cruz Biotechnology), and control siRNA (Santa Cruz Biotechnology) using Lipofectamine-3000 transfection reagent (Invitrogen) according to the manufacturer's instruction. The cells were harvested at $72 \mathrm{~h}$ post-transfection, and assayed by western blot.

\section{In vivo nude mice model}

BALB/c Nude mice $(n=10)$ were purchased from Charles River Laboratories (Wilmington, MA,). These six to eight-week old, specific-pathogen-free, female mice were housed in Biologic Resources Laboratory (BRL) at University of Illinois at Chicago (UIC) and utilized in accordance with the UIC Animal Care Committee (ACC) and Office of Animal Care and Institutional Biosafety (OACIB) guidelines. The animals were subcutaneously injected bilaterally with $1.2 \times 10^{6}$ cells in $200 \mu \mathrm{l}$ of 50:50 Matrigel / PBS (phosphate buffered saline) into the hind flank [25]. At 16 days post-tumor challenge, mice were euthanized by IP injection of sodium pentobarbital (100 mg per $\mathrm{kg}$ body weight) followed by cervical dislocation, and tumors were collected and analyzed. The weight of the tumors was measured, and the tumor volume (V) was calculated from caliper measurements using previously published formulas $\mathrm{V}=\left(\mathrm{W}^{2} \times \mathrm{L}\right) / 2$ [26]. Fresh tumors were fixed in $10 \%$ neutral buffered formalin followed by paraffin embedding. For immunofluorescence staining (IF), slides were incubated in $5 \%$ BSA with $0.1 \%$ goat serum in PBS for $60 \mathrm{~min}$ at room temperature to reduce nonspecific background. The samples were incubated overnight at
$4{ }^{\circ} \mathrm{C}$ with primary anti-E-cadherin, anti- $\beta$-catenin, and anti-Vimentin antibodies (Santa Cruz Biotechnology Inc.) at 1:100 dilution. The samples were then incubated with secondary antibodies and DAPI for $1 \mathrm{~h}$ at room temperature, and examined with confocal microscope as described before [27-29]. BrdU staining was performed as previously described [30]. Protein expression in tumor tissues was detected by western blot as described above.

\section{Statistical analysis}

All the data in graphs were represented by the mean \pm SD. All statistical tests were 2 -sided. The $p$-values $<0.05$ were considered statistically significant. All the $p$-values $<0.05,<0.01$ and $<0.001$ were represented by one, two and three asterisks on the bars in the figures, respectively. Because Welch's $t$-test is more reliable under the conditions of unequal variances and unequal sample sizes for the two-sample comparisons [31, 32], Welch's $t$-test was utilized for all the two-group comparison. The differences among more than two groups were analyzed with One-way ANOVA using Turkey method to adjust multiple comparisons. The Welch's $t$-test and One-way ANOVA were conducted with GraphPad Prism 5 (GraphPad Software, Inc. La Jolla, CA USA). To investigate the dynamic effects of SNX27-KD on cell migration comparing to the WT cells, the group effects from 24 to $72 \mathrm{~h}$ (Fig. 2A) and from 2 to $20 \mathrm{~h}$ (Fig. 2B) were tested using generalized linear mixed models. The statistical analyses were performed using SAS version 9.4 (SAS Institute, Inc., Cary, NC, USA).

\section{Results}

The expressional level of SNX27 in different breast cancer cell lines

In order to compare the difference in expression of SNX27 in different malignant breast cancer cell lines, we collected 7 breast cancer cell lines with different levels of aggression. As these breast cancer cell lines are derived from clinical tumors with various features, the categorization, molecular information, protein expression and invasiveness are also different. For instance, MDAMB-231 cells are invasive while MCF-7 cells are noninvasive. Meanwhile, MCF-10AH1 cells are the least aggressive cancer cells [33]. Equal amounts of cell lysis were 

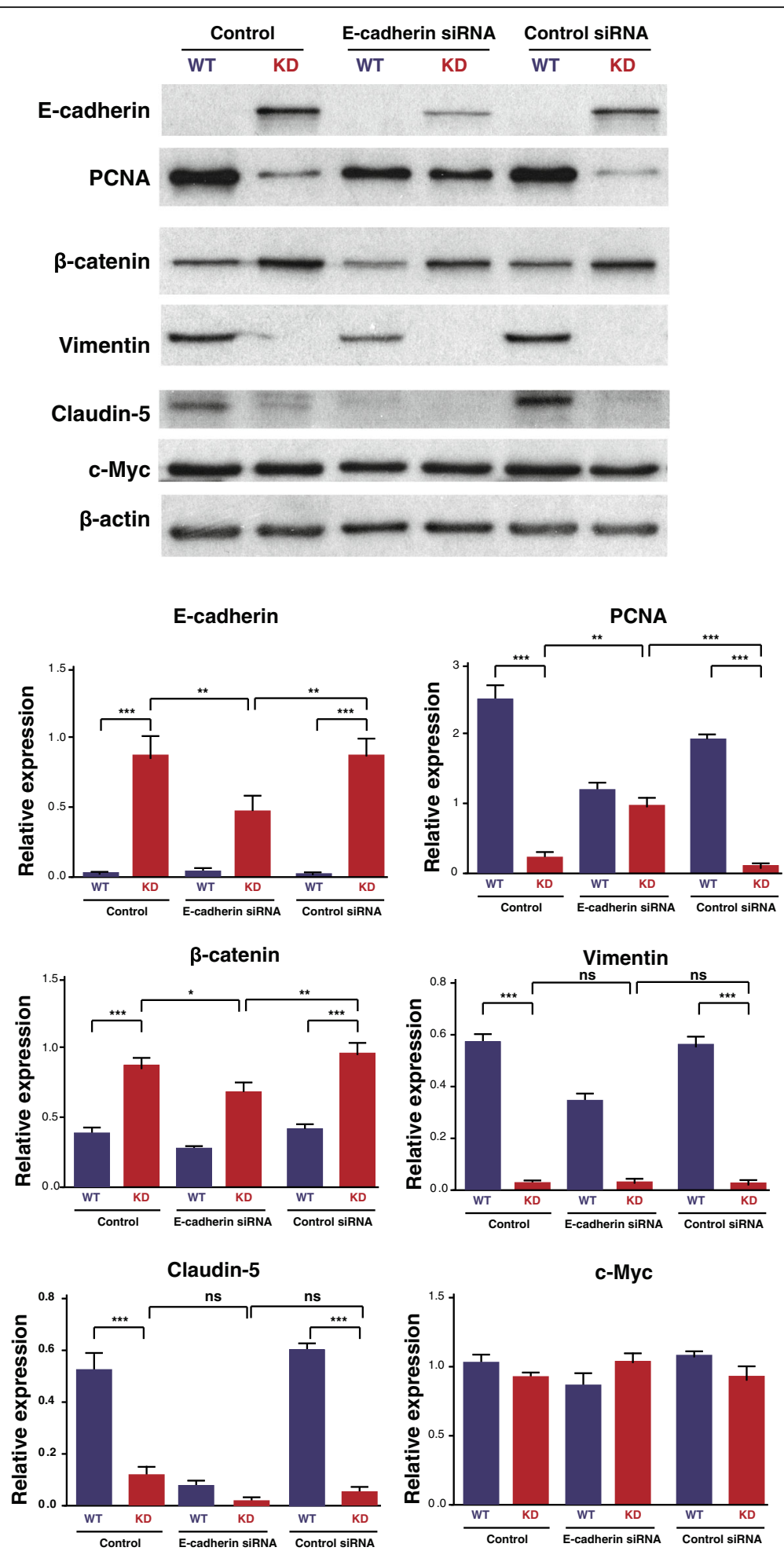

Fig. 5 Confirmation the effect of SNX27 knockdown on E-cadherin activity by siRNA transfection. SNX27-KD and WT cells (50-60\% confluence in 12-well plates) were transfected with E-cadherin siRNA. Lysates were blotted with anti-E-cadherin, anti-PCNA and anti-EMT-related markers. The SNX27-KD MDA-MB-231 cells transfected with E-cadherin siRNA were significantly decreased the E-cadherin expression compared with cells treated with control siRNA and transfection reagent control. The expression of PCNA, the cell proliferation marker, was increased in SNX27-KD cells transfected with E-cadherin siRNA. Data are analyzed with One-way ANOVA adjusting multiple comparisons with Turkey method, and expressed with mean \pm SD from six independent experiments $(n=6)$. ns: no significantly difference, ${ }^{*} p<0.05,{ }^{* *} p<0.01,{ }^{* * *} p<0.001$ 


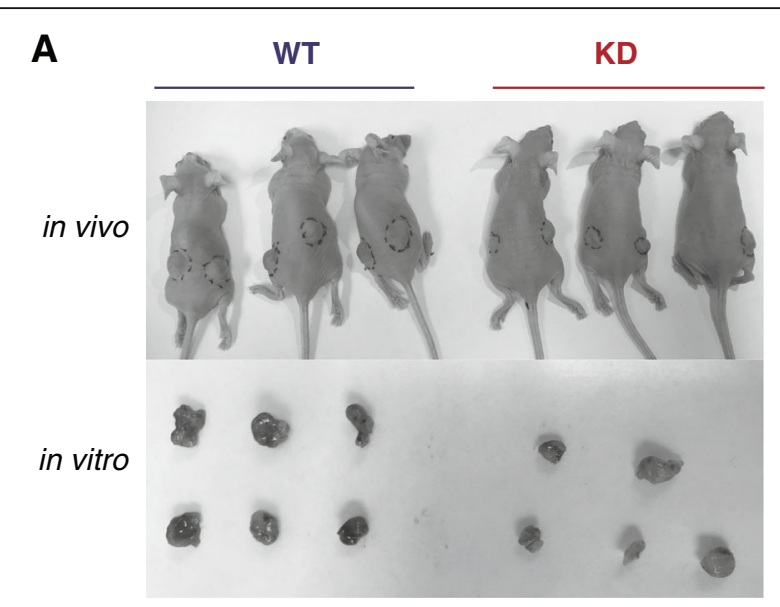

B
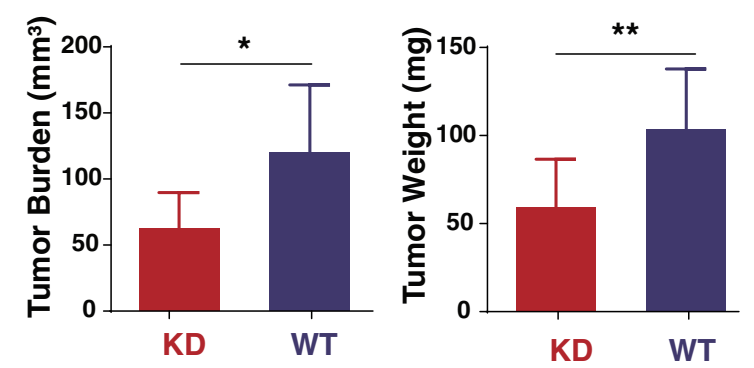

Fig. 6 Breast cancer of SNX27-KD MDA-MB-231 cells grew less than that of WT MDA-MB-231 cells in a nude mouse model. a Representative tumors harvested from the mice ( $n=5$ per group) which challenged with SNX27-KD and WT MDA-MB-231 breast cancer cells were showed in vivo and in vitro. $\mathbf{b}$ Volume and weight of tumors ( $n=9$ per group) harvested from the mice injected with SNX27-KD MDA-MB-231 cells was significantly lower than that of wildtype cancer cells. Data are analyzed with Welch's t-test, and expressed with mean \pm SD. ${ }^{*} p<0.05$ vs. WT control, ${ }^{* *} p<0.01$ vs. WT control

analyzed by western blot. The results showed that SNX27 expression in MDA-MB-231 was the highest level among the seven aggressive breast cancer cell lines, about three folds greater than MCF-10AH1's expression (Fig. 1a).

\section{Establishment of the SNX27 knock-down (KD) clone in MDA-MB-231 cells}

To investigate the effects of SNX27 on tumor cell growth, we generated an inducible lentiviral-mediated shRNA expression system to suppress the expression of SNX27 in MDA-MB-231 cells, which showed the highest SNX27 translational level as described above. Puromycin-resistant clones were treated with doxycycline to induce shRNA expression. Expression of the red fluorescent protein marker indicative of shRNA expression could be detected $48 \mathrm{~h}$ post-induction; at this point expression of SNX27 remained but was reduced in the SNX27 KD cells compared to the WT control $(p<0.01)$ (Fig. 1b). After $72-96 \mathrm{~h}$ treatment, the expression level of SNX27 was below the threshold of detection (Fig. 1c) and about $90 \%$ of SNX27 expression was suppressed in KD cells compared with mock transfection. The reduced SNX27 expression in the clones was persistent which indicated that we established a stable SNX27 knockdown in MDA-MB-231 cells.

\section{SNX27 knockdown reduced cell proliferation and cell migration}

After establishing the SNX27-KD clone in MDA-MB-231 cells, we then examined the cell proliferation of SNX27KD cells by the MTT assay, which is a colorimetric assay for assessing viable cell metabolic activity. Our data showed that cell proliferation was significantly reduced in SNX-KD cells after $24-72 \mathrm{~h}$ incubation $(p<0.01)$ (Fig. 2a), indicating that the expression level of SNX27 is important in regulating cell proliferation.

To investigate the role of SNX27 in cell migration, we conducted a wound-healing experiment. Our data showed that SNX27-KD cells healed the wound area significantly slower than the WT cells $(p<0.01)$ (Fig. 2b). It took $12 \mathrm{~h}$ and $21 \mathrm{~h}$ for KD cells to cover the 50 and $100 \%$ of wound area, respectively, whereas the WT could heal the $50 \%$ of wound area within $8 \mathrm{~h}$ and $100 \%$ of the area in 16-18 h (Fig. 2c). Statistic analysis showed that SNX27 knockdown significantly reduced cell migration starting from $6 \mathrm{~h}$ post wound healing (Fig. 2b).

\section{SNX27 KD changed colony formation in soft agar and altered EMT regulators}

Colony formation is a hallmark of cancer cell malignancy in vitro [24]. As shown in Fig. 3, knockdown of SNX27 significantly suppressed the colony formative capability of MDA-MB-231 cells (Fig. 3a). The colony size of SNX27 KD was smaller than that in the WT cells (Fig. 3b). We also counted the colony numbers. We found that the colony numbers of SNX-27-KD MDA-MB-231 cells were statistically fewer compared to those from the WT cells (SNX27 KD vs. WT, $p<0.01$ ) (Fig. 3c).

To elucidate the mechanism of how knocking down SNX27 leads to suppressed cancer cell proliferation and migration, we investigated the expression of EMT marker proteins. Our data showed that SNX27-KD significantly increased expression of $\beta$-catenin and E-cadherin, whereas the EMT regulatory marker Vimentin was significantly suppressed (Fig. 4a). As the major cytoskeletal component of mesenchymal cells, Vimentin is often used as a marker of mesenchymally-derived cells or cell-undergoing EMT. Here we found that Vimentin expression was suppressed after knockdown of SNX27 in MDA-MB-231 cells. Claudin-5 is a tight junction protein, which is highly expression in breast cancer patient with the high-risk metastasis and reoccurrence [34]. SNX27-KD cells showed significantly lower Claudin-5 expression in western blots (Fig. 4a). 

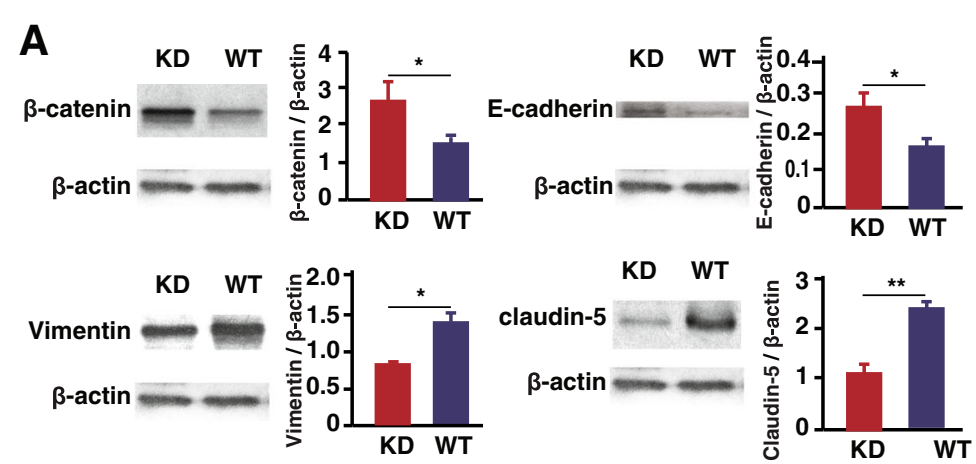

B

KD

WT
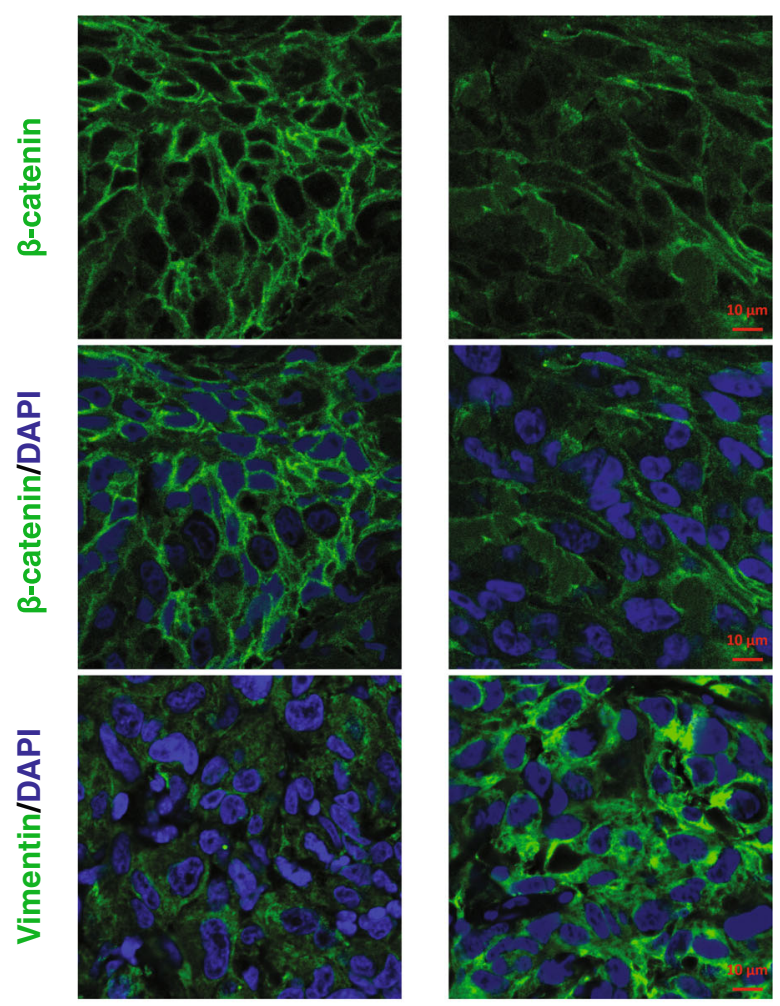

C

$$
\text { KD }
$$

WT
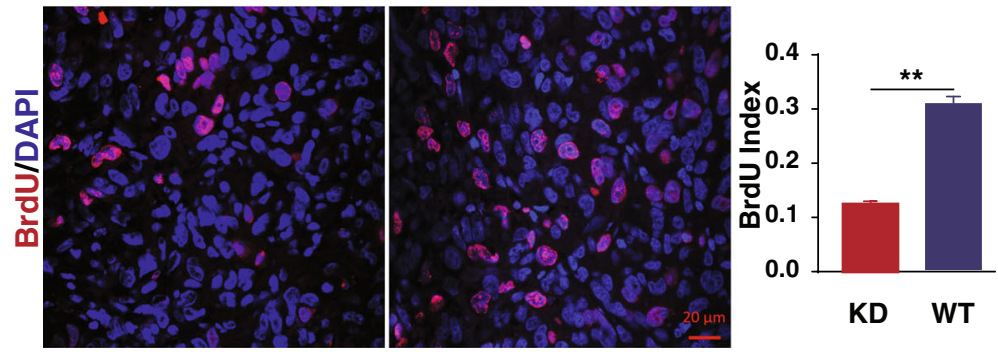

Fig. 7 (See legend on next page.) 
(See figure on previous page.)

Fig. 7 Expression of critical EMT regulators in tumors from nude mice. a SNX27-KD MDA-MB-231 cells accelerated the protein expression of Ecadherin and $\beta$-catenin, and decelerated the protein expression of Vimentin and Claudin- 5 in the tumors isolated from the nude mice model injected with breast cancer cells. Data are analyzed with Welch's t-test, and expressed with mean \pm SD from three independent experiments $(n=$ 3). ${ }^{*} p<0.05$ vs. WT control. ${ }^{* *} p<0.01$ vs. WT control. $\mathbf{b}$ Immunofluorescence staining of $\beta$-catenin and Vimentin was shown that these proteins were expressed in tumors from SNX27-KD injected mice and WT MDA-MB-231 breast cancer cells. Scale bar is $10 \mu \mathrm{m}$. Duplicate samples of each wafer were included in three independent experiments $(n=3)$. c Cell proliferation in the tumor tissue of mice injected with SNX27-KD cells were decelerated compared with wildtype cells by immunofluorescence staining of BrdU (scale bar is $20 \mu \mathrm{m}$ ). BrdU index (number of cell stained with BrdU / number of total cell) was significantly higher in mice injected with wildtype MD-MB-231 cells compared with SNX27-KD cells. Duplicate samples of each wafer were included in three independent experiments $(n=3)$. ${ }^{* *} p<0.01$ vs. WT control

However, there was no significant difference of c-Myc expression between SNX27-KD and WT MDA-MB-231 cells. c-Myc is often constitutively expressed in cancer, which leads to increased expression of many genes, including cell proliferation related genes. Immunostaining data also showed the same trend of EMT-related protein expression in MDA-MB-231 breast cancer cells (Fig. 4b).

We further blocked the expression level of E-cadherin in SNX27-KD and WT MDA-MB-231 cells to see whether there were any influences on cell proliferation and junctions. The expression of cell proliferation marker (PCNA) was increased after E-cadherin siRNA transfection, which indicated that the cell proliferation phenotype of SNX27-KD cells could be partially reversed (Fig. 5). E-cadherin siRNA in SNX 27 KD MDA-MB-231 breast cancer cells also reduced $\beta$-catenin, which is known to bind with E-cadherin in cell junctions, but did not significantly affect tight junction protein Claudin 5 or proliferation regulator c-myc. The WT cells already have very low level of E-cadherin protein, which is untestable by western blots reversed (Fig. 5a). The reduced PCNA in WT cells was observed in both E-cadherin siRNA group and Control siRNA group. It indicated that the reduced PCNA in WT cells is not specifically due to the E-cadherin siRNA.

\section{Impact of SNX27 knockdown on tumor growth and EMT regulators in vivo}

Direct orthotopic or heterotopic injection of breast cancer cells into the mouse have been used to replicate the changes of cells in vitro [35-41]. These traditionally used xenograft models allow the proliferation of human tumor cells in the mouse model. To investigate the impact of SNX27 knockdown on tumor outgrowth, we adapted the breast cancer xenograft nude mouse model by injecting SNX27-KD or WT MDA-MB-231 cells. We found that tumors were significantly larger and heavier in mice injected with the wildtype MDA-MB-231 cells $(n=5)$, compared to mice injected with SNX27-KD MDA-MB-231 cells $(\mathrm{n}=5)(p<0.05)$ (Fig. 6).

We then tested the markers of EMT and tight junction proteins in the tumors. Western blot analysis showed that the SNX27-KD-induced tumors had significantly increased E-cadherin and $\beta$-catenin, but ablated expression levels of Vimentin and Claudin-5 (Fig. 7a). Immunofluorescence staining showed increased $\beta$-catenin and reduced Vimentin in SNX27-KD injected mice, compared to that in WT MDA-MB-231 breast cancer cells (Fig. 7b). Furthermore, proliferation assay of BrdU index (number of cell stained with BrdU / number of total cell) was significantly higher in mice injected with WT MDMB-231 cells, compared with mice injected with SNX27-KD cells (Fig. 7c), suggesting more cell growth in the WT breast cancer cells in vivo.

\section{Discussion}

Here, we have demonstrated that SNX27 plays a novel and crucial role in breast tumor cell growth. Knockdown of SNX27 leads to expression changes of E-cadherin, $\beta$-catenin and Claudin-5, which facilitate adhesion formation, and reduction of Vimentin, which is a critical transcription factor in EMT. The proliferation and collective migration of SNX27-KD MDA-MB-231 cancer cells were significantly reduced. The suppressed proliferation can be reversed in the SNX27-KD cells with increasing PCNA, the cell proliferation marker, using E-cadherin siRNA transfection (Fig. 5). These differences were further confirmed in the nude mouse model in vivo. Overall, knockdown of SNX27 reduced the growth of MDA-MB-231 breast cancer cells (Fig. 8).

To elucidate the mechanism of how SNX27 knockdown impacted the tumor cell behavior and phenotype, we assessed the effect of SNX27 knockdown on biomarkers of EMT. In our study, knockdown of SNX27 markedly increased the expression of E-cadherin and $\beta$-catenin. Confocal imaging also detected E-cadherin and $\beta$-catenin location mainly at the cell membranes after SNX27 knockdown, indicating increased cell stability. The location of $\beta$-catenin at the cell membrane in the SNX27 KD cells suggests increased cell adherence, rather than cell proliferation which marked by nuclear translocation of $\beta$ catenin. EMT is a cellular program that allows polarized, immotile epithelial cells to convert to motile mesenchymal cells, enabling carcinoma invasion and metastasis. Controlling or blocking EMT processes is a promising target in developing anti-cancer drugs' [42-44]. EMT is dynamically controlled by various proteins [45-50]. The role of SNX27 in inhibiting EMT should be further studied in vivo in future research. 


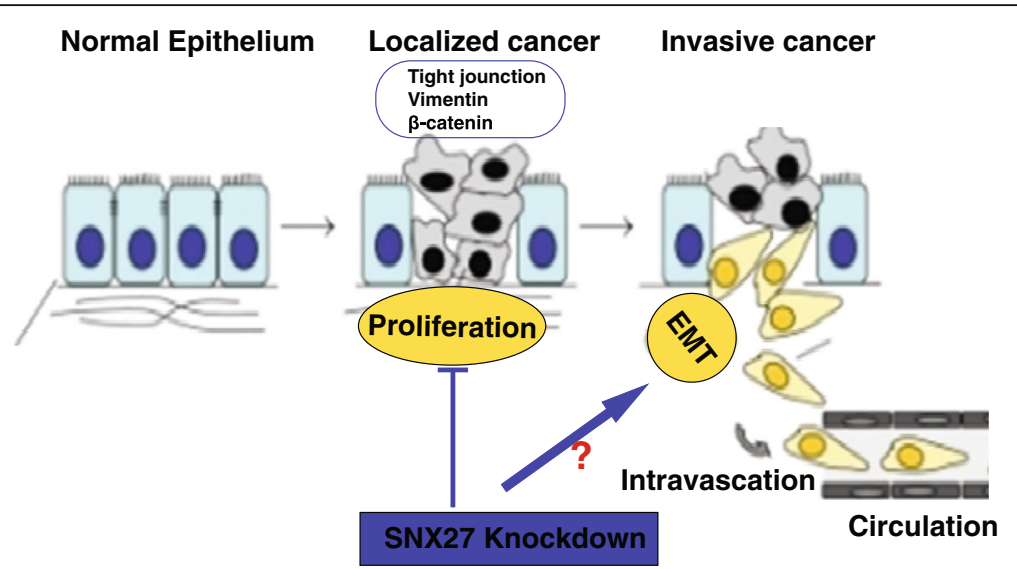

Fig. 8 The working model of SNX27 knockdown in the cancer development. Knockdown of SNX27 inhibits the proliferation and decreases the expression of Vimentin and Claudin-5, and increases the expression of E-cadherin and $\beta$-catenin, which impact on the cell adhesion and migrate. SNX27 could be considered a potential molecular target for controlling cancer growth and development

The importance of SNX27 in breast cancer development was confirmed in vivo with the xenograft nude mouse model. Our data indicated that SNX27 may play a crucial role in cancer cell proliferation, which is consistent with previous reports that SNX27 is required for HeLa and mpkCCD cell migration [17]. Here, the up-regulation of E-cadherin and $\beta$-catenin, and down-regulation of Vimentin and Claudin-5 was detected in the nude mice after injecting SNX27-KD MDA-MB-231 cells. Our results suggest the SNX27 regulates E-cadherin, one of the tumor suppressors, thus decreasing cell proliferation.

In the current study, we also detected that knockdown of SNX27 significantly suppressed the expression of Vimentin in breast cancer cells. The dramatic reduction of Vimentin in SNX27 KD cells is very interesting. Vimentin connects mechanotransduction webs within cells, from focal adhesions to cytoskeletal proteins, such as actin, microtubules, and nuclear cytoskeleton nesprins, to modulate cell spreading and adhesion, and control the directional migration of cancer cells [51]. Many basic and clinical studies have found Vimentin to be a poor prognostic biomarker for breast cancer [52, 53]. Knockdown of Vimentin can also result in the lower expression of Slug and reduce cell migration and proliferation [51]. Thus, the SNX27-related depletion of Vimentin may further stabilize the cytoskeletal architecture within cells to reduce cell motility. SNX27 may mainly affect tumor cell EMT by altering the expression of EMT-regulating proteins, thus reducing the tumor growth and migratory properties.

Interestingly, we found that SNX27 KD could significantly reduce tight junction protein Claudin- 5 expression. Claudins are major adhesion molecules in tight junctions (TJs) and are strongly expressed in various cancers [54]. Claudin- 5 has been found to be highly expressed in breast cancer patients with high-risk metastasis and reoccurrence [34]. SNX27 KD significantly reduced the amount of Claudin-5 and decreased the cell-to-cell tight junctions that made the tumor cells "glue" together. SNX27 contains a PSD95, Dlg1, ZO-1 (PDZ)-binding motif which promotes recycling of internalized transmembrane proteins from endosomes to the plasma membrane. A proteomics study has indicated that interactions between SNX27 and ZO-2 play a key role in tight junction maintenance and function [3]. Further studies are needed to understand the mechanisms of how SNX27 interacts with TJ proteins, including Claudin-5.

One limitation of the current study is that we did not have SNX27 completely knockout in the MDA-MB-231 cells. We wound expect a greater effect on cellular proliferation and the EMT pathway after complete knockout of the SNX27 from the breast cancer cells. Also, we used the xenograft model by injecting the cells in the back flank of nude mice, which does not reflect the real development of breast cancer occurring in the mammary gland. The role of SNX27 should be further studied in a chemical-induced or a transgenic breast cancer model. In the future, we will also plan to determine the role of SNX27 in other cancer cells.

\section{Conclusions}

In conclusion, we have demonstrated a novel function for SNX27 in regulating the growth of cancer cells. Collectively, knockdown of SNX27 markedly suppressed the proliferation, migration and colony formation ability of breast cancer cells. The knockdown of SNX27 resulted in a loss of aggressiveness of cancer cells in vitro and in vivo. SNX27 plays a crucial role in tumor progression. Our findings provide insights into manipulating SNX27 as a new target gene to control tumor growth and development. 


\section{Abbreviations}

ELISA: Enzyme-linked immunosorbent assay; EMT: Epithelial-mesenchymal transition; GLUT1: Glucose transporter 1; IF: Immunofluorescence; KD: Knockdown; MTT: 3-(4,5-Dimethylthiazol-2-yl)-2,5-Diphenyltetrazolium Bromide; PDZ: PSD95, Dlg1, ZO-1; PX: Phox-homology; SNX27: Sorting Nexin 27; TJ: Tight junction; WT: Wild type

\section{Acknowledgements}

Kendy Li was from the Langley High school, 6520 Georgetown Pike, McLean, VA. He presented part of the study in an abstract in the Experimental Biology 2015 [55], Regional Science and Engineering Fair (March 2015) as the Grand Prize winner, and the Intel International Science and Engineering Fair (Intel ISEF, 2015) as a Finalist. We would like to thank Dr. Martin Playford at $\mathrm{NIH}$ for providing SNX27 KD cell lines. We would like to thank Dr. Danika Bakke and Shari Garrett for proofreading the manuscript.

\section{Authors' contributions}

JS secured research funding, designed the study, analyzed data, and finalized the manuscript; JZ, KL, YZ, SW, RL and JT performed experiments and collected and analyzed data; JZ and $\mathrm{KL}$ drafted the article; and $Y X$ provided support for the study design and statistical analysis. All authors were involved in writing the manuscript and reviewed and approved the final version.

\section{Funding}

This project was supported by the NIDDK R01DK105118-01, R01DK114126, DOD CDMRP log No BC160450P1 and UIC Cancer Center funds to Jun Sun. The funding bodies were not involved in the design of this study, collection of data, analysis of data, interpretation of data, or in the writing and submitting of this manuscript for publication.

\section{Availability of data and materials}

The datasets used and analyzed during the current study are available from the corresponding author on reasonable request.

\section{Ethics approval and consent to participate}

Animal studies were approved by the Biologic Resources Laboratory (BRL) at University of Illinois at Chicago (UIC), carried out under animal license guidelines of the UIC Animal Care Committee (ACC) and Office of Animal Care and Institutional Biosafety (OACIB).

\section{Consent for publication}

Not applicable.

\section{Competing interests}

The authors declare that they have no competing interests.

\section{Author details}

${ }^{1}$ Division of Gastroenterology and Hepatology, Medicine, University of Illinois at Chicago, 840 S Wood Street, Room 704 CSB, MC716, Chicago, IL 60612, USA ${ }^{2}$ Liberal Arts \& Human Sciences, Virginia Polytechnic Institute and State University, Blacksburg, Virginia, USA. 'ㄹepartment of Biochemistry, Rush University, Chicago, IL, USA. ${ }^{5}$ Section of Inflammation and Cardiometabolic Diseases, National Heart, Lung, and Blood Institute (NHLBI), National Institutes of Health, Bethesda, MD, USA

\section{Received: 2 November 2018 Accepted: 29 May 2019}

Published online: 10 June 2019

\section{References}

1. Gallon M, Cullen PJ. Retromer and sorting nexins in endosomal sorting. Biochem Soc Trans. 2015;43(1):33-47.

2. Carlton JG, Cullen PJ. Sorting nexins. Curr Biol. 2005;15(20):R819-20.

3. Zimmerman SP, Hueschen CL, Malide D, Milgram SL, Playford MP. Sorting nexin 27 (SNX27) associates with zonula occludens-2 (ZO-2) and modulates the epithelial tight junction. The Biochemical journal. 2013;455(1):95-106.

4. Loo LS, Tang N, Al-Haddawi M, Dawe GS, Hong W. A role for sorting nexin 27 in AMPA receptor trafficking. Nat Commun. 2014;5:3176.

5. Gallon M, Clairfeuille T, Steinberg F, Mas C, Ghai R, Sessions RB, Teasdale RD, Collins BM, Cullen PJ. A unique PDZ domain and arrestin-like fold interaction reveals mechanistic details of endocytic recycling by SNX27retromer. Proc Natl Acad Sci U S A. 2014;111(35):E3604-13.

6. Steinberg F, Gallon M, Winfield M, Thomas EC, Bell AJ, Heesom KJ, Tavare JM, Cullen PJ. A global analysis of SNX27-retromer assembly and cargo specificity reveals a function in glucose and metal ion transport. Nat Cell Biol. 2013;15(5):461-71.

7. Balana B, Bahima L, Bodhinathan K, Taura JJ, Taylor NM, Nettleton MY, Ciruela F, Slesinger PA. Ras-association domain of sorting nexin 27 is critical for regulating expression of GIRK potassium channels. PLoS One. 2013;8(3):e59800.

8. Nakagawa T, Asahi M. beta1-adrenergic receptor recycles via a membranous organelle, recycling endosome, by binding with sorting nexin27. J Membr Biol. 2013;246(7):571-9.

9. MacNeil AJ, Pohajdak B. Polarization of endosomal SNX27 in migrating and tumor-engaged natural killer cells. Biochem Biophys Res Commun. 2007; 361(1):146-50.

10. Ahmad A. Pathways to breast cancer recurrence. ISRN oncology. 2013;2013: 290568.

11. Cheung KJ, Ewald AJ. Illuminating breast cancer invasion: diverse roles for cell-cell interactions. Curr Opin Cell Biol. 2014;30:99-111.

12. Feng Y, Spezia M, Huang S, Yuan C, Zeng Z, Zhang L, Ji X, Liu W, Huang B, Luo W, et al. Breast cancer development and progression: risk factors, cancer stem cells, signaling pathways, genomics, and molecular pathogenesis. Genes \& diseases. 2018;5(2):77-106.

13. Voulgari A, Pintzas A. Epithelial-mesenchymal transition in cancer metastasis: mechanisms, markers and strategies to overcome drug resistance in the clinic. Biochim Biophys Acta. 2009;1796(2):75-90.

14. Jung $H Y$, Fattet $L$, Yang J. Molecular pathways: linking tumor microenvironment to epithelial-mesenchymal transition in metastasis. Clinical cancer research : an official journal of the American Association for Cancer Research. 2015;21(5):962-8.

15. Imamichi Y, Menke A. Signaling pathways involved in collagen-induced disruption of the E-cadherin complex during epithelial-mesenchymal transition. Cells Tissues Organs. 2007;185(1-3):180-90.

16. Baranwal S, Alahari SK. Molecular mechanisms controlling E-cadherin expression in breast cancer. Biochem Biophys Res Commun. 2009;384(1):6-11.

17. Valdes JL, Tang J, McDermott MI, Kuo JC, Zimmerman SP, Wincovitch SM, Waterman CM, Milgram SL, Playford MP. Sorting nexin 27 protein regulates trafficking of a p21-activated kinase (PAK) interacting exchange factor (betapix)-G protein-coupled receptor kinase interacting protein (GIT) complex via a PDZ domain interaction. J Biol Chem. 2011;286(45):39403-16.

18. Sun L, Hu X, Chen W, He W, Zhang Z, Wang T. Sorting nexin 27 interacts with Fzd7 and mediates Wnt signalling. Biosci Rep. 2016;36(1):e00296.

19. Harrington KJ, Syrigos KN. The role of E-cadherin-catenin complex: more than an intercellular glue? Ann Surg Oncol. 2000;7(10):783-8.

20. Lu R, Liu X, Wu S, Xia Y, Zhang YG, Petrof EO, Claud EC, Sun J. Consistent activation of the beta-catenin pathway by Salmonella type-three secretion effector protein AvrA in chronically infected intestine. Am J Physiol Gastrointest Liver Physiol. 2012;303(10):G1113-25.

21. Murrell M, Kamm R, Matsudaira P. Tension, free space, and cell damage in a microfluidic wound healing assay. PLoS One. 2011;6(9):e24283.

22. Fischer RS, Gardel M, Ma X, Adelstein RS, Waterman CM. Local cortical tension by myosin II guides 3D endothelial cell branching. Current biology : CB. 2009;19(3):260-5.

23. Vicente-Manzanares M, Ma X, Adelstein RS, Horwitz AR. Non-muscle myosin Il takes Centre stage in cell adhesion and migration. Nat Rev Mol Cell Biol. 2009:10(11):778-90.

24. Pan ZY, Yang Y, Pan H, Zhang J, Liu H, Yang Y, Huang G, Yin L, Huang J, Zhou WP. Lentivirus-mediated TPD52L2 depletion inhibits the proliferation of liver cancer cells in vitro. Int J Clin Exp Med. 2015;8(2):2334-41.

25. Kocaturk B, Versteeg HH. Orthotopic injection of breast cancer cells into the mammary fat pad of mice to study tumor growth. J visualized experiments JoVE. 2015;(96).

26. Faustino-Rocha A, Oliveira PA, Pinho-Oliveira J, Teixeira-Guedes C, SoaresMaia R, da Costa RG, Colaco B, Pires MJ, Colaco J, Ferreira R, et al. Estimation of rat mammary tumor volume using caliper and ultrasonography measurements. Lab animal. 2013;42(6):217-24.

27. Liao AP, Petrof EO, Kuppireddi S, Zhao Y, Xia Y, Claud EC, Sun J. Salmonella type III effector AvrA stabilizes cell tight junctions to inhibit inflammation in intestinal epithelial cells. PLoS One. 2008;3(6):e2369.

28. Lu R, Wu S, Zhang Y, Xia Y, Huelsmann EJ, Lacek AT, Nabatiyan A, Richards MH, Narasipura SD, Lutgen $V$, et al. HIV infection accelerates gastrointestinal tumor outgrowth in NSG-HuPBL mice. AIDS Res Hum Retrovir. 2014;30(7):677-84. 
29. Lu R, Wu S, Zhang YG, Xia Y, Zhou Z, Kato I, Dong H, Bissonnette M, Sun J. Salmonella protein AvrA activates the STAT3 signaling pathway in Colon Cancer. Neoplasia (New York, NY). 2016;18(5):307-16.

30. Lu R, Wu S, Liu X, Xia Y, Zhang YG, Sun J. Chronic effects of a Salmonella type III secretion effector protein AvrA in vivo. PLoS One. 2010;5(5):e10505.

31. Ruxton GD. The unequal variance t-test is an underused alternative to Student's t-test and the Mann-Whitney U test. Behav Ecol. 2006;17(4):688-90.

32. Xia Y, Sun J, Chen D-G. Statistical analysis of microbiome data with R. Nature/Springer. 2018

33. Qu Y, Han B, Yu Y, Yao W, Bose S, Karlan BY, Giuliano AE, Cui X. Evaluation of MCF10A as a reliable model for Normal human mammary epithelial cells. PLoS One. 2015;10(7):e0131285

34. Sugimoto $H$, Nagahara $M$, Bae $Y$, Nakagawa $T$, Ishikawa $T$, Sato $T$, Uetake $H$, Eishi Y, Sugihara K. Clinicopathologic relevance of claudin 5 expression in breast cancer. Am J Clin Pathol. 2015;143(4):540-6.

35. Di Cello F, Shin J, Harbom K, Brayton C. Knockdown of HMGA1 inhibits human breast cancer cell growth and metastasis in immunodeficient mice. Biochem Biophys Res Commun. 2013;434(1):70-4.

36. Jami MS, Hou J, Liu M, Varney ML, Hassan H, Dong J, Geng L, Wang J, Yu F, Huang $X$, et al. Functional proteomic analysis reveals the involvement of KIAA1199 in breast cancer growth, motility and invasiveness. BMC Cancer. 2014;14:194

37. Segatto I, Berton S, Sonego M, Massarut S, Fabris L, Armenia J, Mileto M, Colombatti A, Vecchione A, Baldassarre $G$, et al. p70S6 kinase mediates breast cancer cell survival in response to surgical wound fluid stimulation. Mol Oncol. 2014;8(3):766-80.

38. Ooms LM, Binge LC, Davies EM, Rahman P, Conway JR, Gurung R, Ferguson DT, Papa A, Fedele CG, Vieusseux $J$, et al. The inositol polyphosphate 5phosphatase PIPP regulates AKT1-dependent breast Cancer growth and metastasis. Cancer Cell. 2015;28(2):155-69.

39. Stengel C, Newman SP, Leese MP, Thomas MP, Potter BV, Reed MJ, Purohit A, Foster PA. The in vitro and in vivo activity of the microtubule disruptor STX140 is mediated by Hif-1 alpha and CAIX expression. Anticancer Res. 2015;35(10):5249-61.

40. Yano S, Takehara K, Miwa S, Kishimoto H, Tazawa H, Urata Y, Kagawa S, Bouvet M, Fujiwara T, Hoffman RM. In vivo isolation of a highly-aggressive variant of triple-negative human breast Cancer MDA-MB-231 using serial Orthotopic transplantation. Anticancer Res. 2016;36(8):3817-20.

41. Khaled M, Belaaloui G, Jiang ZZ, Zhu X, Zhang LY. Antitumor effect of Deoxypodophyllotoxin on human breast cancer xenograft transplanted in BALB/c nude mice model. J Infect Chemother. 2016;22(10):692-6.

42. Wang $Y$, Zhou BP. Epithelial-mesenchymal transition in breast cancer progression and metastasis. Chinese journal of cancer. 2011;30(9):603-11.

43. Kaufhold S, Bonavida B. Central role of Snail1 in the regulation of EMT and resistance in cancer: a target for therapeutic intervention. J experimental \& clinical cancer research : CR. 2014;33:62.

44. Steinestel K, Eder S, Schrader AJ, Steinestel J. Clinical significance of epithelial-mesenchymal transition. Clin Transl Med. 2014;3:17.

45. Lamouille $S, X u$ J, Derynck R. Molecular mechanisms of epithelialmesenchymal transition. Nat Rev Mol Cell Biol. 2014;15(3):178-96.

46. Wijnhoven BP, Dinjens WN, Pignatelli M. E-cadherin-catenin cell-cell adhesion complex and human cancer. Br J Surg. 2000;87(8):992-1005.

47. Cai K, Jiang L, Wang J, Zhang H, Wang X, Cheng D, Dou J. Downregulation of beta-catenin decreases the tumorigenicity, but promotes epithelialmesenchymal transition in breast cancer cells. J Cancer Res Ther. 2014;10(4): 1063-70.

48. Yu H, Shen $Y$, Hong J, Xia Q, Zhou F, Liu X. The contribution of TGF- $\beta$ in epithelial-mesenchymal transition (EMT): Down-regulation of E-cadherin via snail. Neoplasma. 2015;62(01):1-15.

49. Schmalhofer O, Brabletz S, Brabletz T. E-cadherin, beta-catenin, and ZEB1 in malignant progression of cancer. Cancer Metastasis Rev. 2009;28(1-2):151-66.

50. Cowin P, Rowlands TM, Hatsell SJ. Cadherins and catenins in breast cancer. Curr Opin Cell Biol. 2005;17(5):499-508.

51. Liu CY, Lin HH, Tang MJ, Wang YK. Vimentin contributes to epithelialmesenchymal transition cancer cell mechanics by mediating cytoskeletal organization and focal adhesion maturation. Oncotarget. 2015;6(18): 15966-83.

52. Yamashita N, Tokunaga E, Kitao H, Hisamatsu Y, Taketani K, Akiyoshi S, Okada S, Aishima S, Morita M, Maehara Y. Vimentin as a poor prognostic factor for triple-negative breast cancer. J Cancer Res Clin Oncol. 2013;139(5): $739-46$
53. Patel NA, Patel PS, Vora HH. Role of PRL-3, snail, cytokeratin and vimentin expression in epithelial mesenchymal transition in breast carcinoma. Breast disease. 2015;35(2):113-27.

54. Jia W, Lu R, Martin TA, Jiang WG. The role of claudin-5 in blood-brain barrier (BBB) and brain metastases (review). Mol Med Rep. 2014;9(3):779-85.

55. Li K, Wu S, Playford M, Sun J. Deletion of sorting nexin 27 reverses epithelial-mesenchymal-transition in highly aggressive breast cancer cells. FASEB J. 2015;29(1 supplement):926.920.

\section{Publisher's Note}

Springer Nature remains neutral with regard to jurisdictional claims in published maps and institutional affiliations.
Ready to submit your research? Choose BMC and benefit from:

- fast, convenient online submission

- thorough peer review by experienced researchers in your field

- rapid publication on acceptance

- support for research data, including large and complex data types

- gold Open Access which fosters wider collaboration and increased citations

- maximum visibility for your research: over $100 \mathrm{M}$ website views per year

At $\mathrm{BMC}$, research is always in progress.

Learn more biomedcentral.com/submissions 